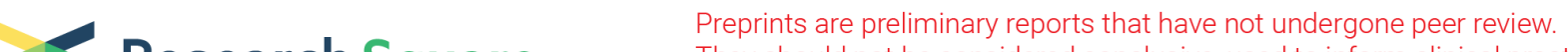 Research Square They should not be considered conclusive, used to inform clinical practice, or referenced by the media as validated information.
}

\section{Influence of Selected Environmental Parameters on Rove Beetle (Coleoptera: Staphylinidae) Communities in Central European Floodplain Forests}

\section{Slavomír Stašiov}

Technical University of Zvolen: Technicka Univerzita vo Zvolene Juraj Litavský ( $\square$ litavskyjuraj@gmail.com )

Comenius University in Bratislava Faculty of Natural Sciences: Univerzita Komenskeho v Bratislave Prirodovedecka fakulta https://orcid.org/0000-0003-1229-1098

\section{Oto Majzlan}

Comenius University in Bratislava Faculty of Natural Sciences: Univerzita Komenskeho v Bratislave Prirodovedecka fakulta

\section{Marek Svitok}

Technical University of Zvolen: Technicka Univerzita vo Zvolene

\section{Peter Fedor}

Comenius University in Bratislava Faculty of Natural Sciences: Univerzita Komenskeho v Bratislave Prirodovedecka fakulta

\section{Research Article}

Keywords: Alluvial forests, Bioindicators, Dynamic activity, Epigeic invertebrates, Staphylinidae

Posted Date: April 19th, 2021

DOI: https://doi.org/10.21203/rs.3.rs-330110/v1

License: (c) (1) This work is licensed under a Creative Commons Attribution 4.0 International License. Read Full License

Version of Record: A version of this preprint was published at Wetlands on November 16th, 2021. See the published version at https://doi.org/10.1007/s13157-021-01496-5. 


\section{Abstract}

Wetlands and especially floodplain forests belong to the most endangered ecosystems in Europe, characterized by complex dynamics of flood and dry periods and providing specific irreplaceable habitats for many organisms, including bioindicators. Many rove beetle species, for instance, are well-known detectors in monitoring ecological change, however, their use in environmental assessment requires to expand the insufficient knowledge on ecological environmental particularities of their assemblages. Therefore, we compared the rove beetle communities in eight habitats of floodplain forests from 2015 to 2016. Staphylinids were sampled by pitfall trapping. We compared the rove beetle taxocoenoses in the floodplain forests and their ecotones alongside three rivers (Danube, Tisa and Begej). We evaluated the impact of plant diversity and cover of vegetation layers, area, circumference and age of forest stands, distance to the forest edge, thickness of the litter layer, physical and chemical properties of soil and leaf litter (conductivity, $\mathrm{pH}, \mathrm{P}, \mathrm{N}, \mathrm{H}, \mathrm{C}$ ) and anthropogenic impact on structure of rove beetle communities. We recorded significant interactions between total dynamic activity of rove beetles and number of plant species in shrub vegetation layer. Species richness was significantly positively correlated with number of plant species in shrub vegetation layer and soil $\mathrm{pH}$, and negatively with relative $\mathrm{H}$ content of soil. We did not find any significant correlation between Shannon diversity, but evenness was negatively linked with species richness of plant communities in shrub layer.

\section{Introduction}

The alluvial landscape is characterized by a diverse composition of habitats. Its structure consists of a mosaic of wetlands, waterways, oxbow lakes, meadows and various types of floodplain forests. Their dynamics is predominantly affected by water regime (Kontriš 1981; Vašíček 1985; Michalko et al. 1986; Ward et al. 1999; Machar 2008; Hughes et al. 2012; Ábrahámová et al. 2014). Floodplain forests are undisputedly dynamic complexes with a high degree of biodiversity (Hughes 2007). For this reason, they are considered as priority biotopes in nature conservation.

Management and conservation of European wetlands requires a sound understanding of both extraordinary species-environment and species-species relationships in the communities, guilds etc. (Fedor 2004; Derunkov 2007, 2009). Moreover, insects (e.g. King and Brazner 1999; Davis et al. 2006; Rothenbücher and Schaefer 2006; Dubovský et al. 2010; Zvaríková et al. 2016; Štefánik and Fedor 2020), including beetles (e.g. Šustek 1994; Dennis et al. 2002; Porhajašová et al. 2008; Skłodowski 2014; Ogai and Kenta 2016; Litavský et al. 2021a, b) generally offers many bioindicator species for effective monitoring ecological change, disturbance and environmental impact. Consequentially, rove beetles are an important component of the terrestrial arthropod communities of wetlands. Species adapted to this dynamic habitat are highly specialized and stenotopic. This predestines them to be useful indicators with high susceptibility to natural changes or anthropogenic impact (Schatz 2007). Because of their worldwide distribution, their ecological significance, and their ecomorphological and behavioural diversity, rove beetles are nowadays becoming an increasingly investigated insect group in the fields of ecology and evolution (Betz et al. 2018). 
Up to now 1,783 species of Staphylinoidea have been reliably known in Slovakian fauna (Zahradník 2017) while in Serbia 883 species have been recorded until now (Stančić 2013; Löbl and Löbl 2015; Majzlan and Litavský 2017). The Staphylinidae, or rove beetles, belong to the largest and most biologically diverse beetle families. The world fauna consists of more than 63,495 described species (Klimaszewski et al. 2018). Representatives of the family are found among euedaphic species in deep soil layers, on the soil surface, on the vegetation up to the canopy of forests, and from marine habitats in the eulittoral zone of the sea up to high mountain zones (Thayer 2005). Moreover, the variety of feeding habits is astonishing (Irmler and Lipkow 2018). Most rove beetles are predatory as adults and larvae, feeding on other, smaller arthropods. Within the family, however, you'll find rove beetles that specialize on a diet of fungal spores, others that eat pollen, and still others that feed on the regurgitated food from ants (Hadley 2020). Because of good knowledge of ecological demands of most Central European species of rove beetles and their distribution in all semi-natural and man-made habitats, many authors consider these organisms to be very suitable bioindicators of anthropogenic environmental changes (Boháč 1990, 1999; Michaels 2007; Boháč and Jahnová 2015; Klimaszewski et al. 2018).

Several authors have studied rove beetles in the wetland biotopes (Irmler 1979; Greenwood et al. 1991; Majzlan and Jászay 1997; Šustek 2003, 2006; Boháč and Bezděk 2004; Derunkov 2004, 2007, 2009; Schatz 2007; Gutiérrez-Chacón et al. 2009; Shepherd 2013; Babenko et al. 2015; Kolesnikova et al. 2016; Irmler and Lipkow 2018). Their research revealed the influence of several factors on the abundance and structure of rove beetle communities in this type of environment (e.g. moisture, temperature and $\mathrm{pH}$ of soil, canopy cover, amount of dead biomass on soil surface, forest stand area and its circuit, habitat type, vegetation composition, fragmentation of landscape, flood characteristics, anthropogenic impact and others). However, the results of some studies contradict each other, and the significance of the influence of individual factors on the formation of rove beetle communities, which was found by various authors, is also different. Therefore, we decided to test the impact of some controversial factors, as well as hitherto unexplored environmental parameters on the structure of rove beetle communities in floodplain forests.

Parallel analyses of staphylinid taxocoenoses in two similar ecosystems in different regions have inspired us to evaluate the impact of a wide range of environmental characteristics on their structure. Therefore, we compared the similar types of habitats in alluvia of three rivers, Danube (Slovakia), Tisa and Begej (Serbia), using 24 different parameters (Table 2) and their influence on staphylinid communities.

\section{Materials And Methods}

\section{Study area}

The research was carried out at eight sites situated in the alluvium of the three rivers: the Danube in Slovakia (S1-S5) and the Tisa (S6, S7) and the Begej in Serbia (S8).

S1 - a fragment of floodplain forest Salici-Populetum. 
S2 - a semi-open habitat along the old arm of the Danube River.

S3 - a semi-open xerothermic habitat at the gravel bar with a shallow layer of soil.

S4 - a shrub-meadow ecotone, located in the floodplain forest Biskupické luhy.

S5 - a hardwood floodplain forest located next to the oxbow lake Biskupické rameno.

S6 - a softwood floodplain forest located in the proximity of the oxbow lake of the Tisa River in the inundation area.

S7 - a meadow-wetland ecotone, located on the border of the SNR "Ritovi donjeg Potisja".

S8 - a hardwood floodplain forest located within the SNR "Carska bara" in the alluvium of the Begej River.

Additional details on the study area are provided in Litavský et al. (2021b).

\section{Sampling}

The research was performed from February 2015 until November 2016. The rove beetles were captured by pitfall trapping (Stašiov 2015), using 0.5 I plastic cups ( $9 \mathrm{~cm}$ in opening diameter) with and $1 \%$ formaldehyde as a fixation fluid (approximately one third of the volume). At each study site, five traps were installed in a line in the distances of $5 \mathrm{~m}$ between neighbouring cups. These transects were placed in the middle of monitored sites. Traps were emptied and refilled approximately in half-month intervals. The contents of five traps at each site and date were put together to represent a composite sample. The material was sorted in the laboratory and the rove beetles subsequently identified to the species level according to Lohse $(1964,1989)$, Assing and Schülke (2012). Specimens were fixed in $75 \%$ ethyl alcohol and deposited at the Faculty of Natural Sciences of the Comenius University in Bratislava. A list of species is organized in accordance with (Newton 2019).

Concerning environmental properties, we decided to monitor the characteristics that could influence the composition of staphylinid communities. Results about these attributes that we recorded, such as stand canopy of individual layers, species richness of individual layers, anthropogenic impact (four levels), fragment's size in which we placed pitfall traps, distance of located traps from another different fragment (edge), circuit of this fragment, age of trees at study sites and average thickness of leaf litter layer, were presented in Litavský et al. $(2018,2021$ b).

At the study sites we estimated the cover of tree, shrub and herb layers and sampled species occurring in individual layers, all in a sampling area of $400 \mathrm{~m}^{2}$. More information on the method of investigation of the vegetation is given in Litavský et al. (2021b).

Samples of soil and leaf litter for chemical analyses were taken on the 8th of June 2016. More detailed information about the methods of analysis of the soil and leaf litter samples, as well as the results of 


\section{Statistical analysis}

Diversity of rove beetle communities was quantified as species richness and by the Shannon diversity (Spellerberg and Fedor 2003; Jost 2006) and evenness (Tuomisto 2012). Dynamic activity of each species was calculated as mean number of individuals caught per trap per day. Composition of rove beetle communities was summarized in the species-by-site matrix of dynamic activities.

Due to relatively low number of sampling sites and high number of environmental variables, we did not build parsimonious models describing diversity and composition patterns, but we adopted an exploratory approach and investigated all species-environment relationships.

In order to investigate patterns of summary community characteristics (total dynamic activity, species richness, Shannon diversity and evenness), we calculated the matrix of pairwise Spearman correlation coefficients between environmental variables and community characteristics.

Principal coordinate analysis (PCoA) based on Bray-Curtis distance was used to visualize similarities in composition of rove beetle communities. The vectors of environmental variables were projected into ordinations in the directions of their maximal correlations with the configuration of sites. Statistical significance of fitted environmental vectors was assessed using permutation tests $(10,000$ permutations).

This exploratory approach allowed us to investigate all species-environment relationships without the risk of missing any important information caused by removal of highly correlated variables. Indeed, the results of such a heuristic analysis should be considered carefully and regarded as a process of generation of new hypotheses rather than a generalization to wider populations.

The analyses were performed in R (R Core Team 2016) using libraries Hmisc (Harrell 2016) and vegan (Oksanen et al. 2016).

\section{Results}

During the whole research, a total of 1,283 rove beetle specimens of 130 species were recorded, including 109 species from Slovakian sites and 35 species from Serbian sites, while 14 species occurred in both countries. The values of total dynamic activity of rove beetles recorded at individual study sites during the research are shown in Table 1. The most abundant species were Ocypus (Pseudocypus) mus (292 captured individuals) and Ocypus (Ocypus) olens (206 captured individuals), both of them were captured only in the Danube River floodplain forests (with no records from Serbia) as well as Staphylinus caesareus (80 ind. captured at 2 Slovakian and 1 Serbian sites). Species such as Drusilla (Drusilla) canaliculata, Ocypus (Angulephallus) brunnipes, Ocypus (Pseudocypus) mus, Ocypus (Matidus) nitens, Ocypus (Ocypus) olens, Philonthus (Philonthus) spinipes and Tasgius (Rayacheila) melanarius were 
recorded at a maximum of 5 sites. Apart from the Drusilla (Drusilla) canaliculata, Tasgius (Rayacheila) melanarius and Philonthus (Philonthus) spinipes, the most frequented species were recorded only at the Slovak sites. Species Omalium caesum, Oxyporus maxillosus (only in Slovakia) and Staphylinus caesareus (in Slovakia and in Serbia) were recorded at four sites. Sixty-eight ( 56 from Slovakian and 14 from Serbian sites) of rove beetles were recorded on one site only for the entire period of research, of which 37 were represented by one individual only. The largest number of individuals refers to the study site S1 (265 ind.) and site S5 (252 ind.), the highest species richness appeared at S5 (40 species) and S3 (39 species). The least individuals as well as species were caught on all Serbian sites.

The highest value of the Shannon's index of rove beetle communities was calculated for the site S2 (3.05) and the highest value of equitability index refers to the site $S 8(0.80)$. The lowest values of Shannon index as well as equitability index of rove beetle communities were recorded at site S1 (2.34/0.30) (Table 1).

The relationships between community characteristics and environmental variables were evaluated using non-parametric correlation analysis. Total dynamic activity of staphylinids showed significant positive relationship with number of plant species in $E_{2}$ vegetation layer (Table 2). Species richness was significantly positively correlated with number of plant species in $\mathrm{E}_{2}$ and soil $\mathrm{pH}$, and negatively with relative $\mathrm{H}$ content of soil. We did not find any significant correlation between Shannon diversity, but evenness was negatively linked with number of plant species in $E_{2}$.

PCoA and associated permutation test revealed that composition of rove beetle communities was significantly related to soil $\mathrm{pH}\left(r^{2}=0.80, \mathrm{p}=0.019\right)$, soil relative $\mathrm{H}$ content $\left(r^{2}=0.76, \mathrm{p}=0.038\right)$ and diversity of $\mathrm{E}_{1}$ layer $\left(\mathrm{r}^{2}=0.75, \mathrm{p}=0.043\right)$. Ocypus (Ocypus) olens (Ocol) and Ocypus (Pseudocypus) mus (Ocmu) preferred fragments with higher soil pH (Fig. 1).

\section{Discussion}

The results of our research showed that the wetland habitats of the Danube, Begej and Tisa Rivers could provide suitable conditions for rove beetle communities with high species richness. Also, according to Kolesnikova et al. (2016), rove beetles are characterized by high species diversity in wetlands and alluvial forest. According to Derunkov (2009), wetland ecosystems in general, especially floodplain forests are key habitats for many rare species, including postglacial relicts. According to this author, the staphylinid community composition in floodplain forests is defined by the eurytopic forest species. This opinion is also supported by the dominant occurrence of Ocypus mus and 0 . olens recorded at studied sites (38.8\% from all caught rove beetles), because both species are typical for the moderately humid or dry forests (Šustek 1992; Massolo et al. 2006).

Similarly, high biodiversity of rove beetle communities in wetlands has been confirmed by several other authors. For instance, Derunkov (2007) recorded in the floodplains of Neman River and its right tributary 
- Shchara River (Belarus) 83 staphylinid species. Majzlan and Jászay (1997) observed 224 staphylinid species in the wetlands along the Morava River (Southwestern Slovakia).

Among other factors, the rove beetles are also related to the quality of leaf litter and soil. An important property of soil is the content of $\mathrm{N}$ and $\mathrm{P}$. Our research revealed that the largest number of individuals were recorded at the site S1 (265 ind.) and site S5 (252 ind.) (Table 1). They were characterized by a relatively high content of these nutrients in soil ( $N(S 1)-0.29 \%$ weighted, $P(S 1)-36.0$ mg.kg-1 $; N(S 5)-$ $0.29 \%$ weighted, $\mathrm{P}$ (S5) - $25.8 \mathrm{mg} \cdot \mathrm{kg}^{-1}$ ) in comparison with other studied sites (within the overall range $\mathrm{N}: 0.15-0.36 \%$ weighted, P: $5.2-84.3 \mathrm{mg}^{\mathrm{kg}} \mathrm{kg}^{-1}$ ). The content of these nutrients in soil and in the litter probably also had an effect on equitability of rove beetle communities, because the highest values equitability index was also recorded at site $S 8(0.80)$ (Table 1 ) with the highest $P$ content in the soil (84.3 mg. $\left.\mathrm{kg}^{-1}\right)$ and also in the litter layer $\left(407 \mathrm{mg} \cdot \mathrm{kg}^{-1}\right.$; within the overall range $\left.85-407 \mathrm{mg} \cdot \mathrm{kg}^{-1}\right)$ and with the second highest $\mathrm{N}$ content in the soil $(0.31 \%$ weighted) within the studied sites. The content of $\mathrm{N}$ and $\mathrm{P}$ in soil may have an indirect impact (through food resources of rove beetles - e.g. fungi, saprophagous) on the food available for rove beetles. Soil humus rich in nitrogen and phosphorus is an attractive source for fungi and saprophagous organisms. Therefore, such material is decomposed by activity of decomposers and saprophagous species more quickly (Wittich 1942, 1943). The importance of nitrogen and phosphorus as the main elements determining the animal production and food resources for invertebrates, including rove beetles, has been reported by Dunger (1958). During the same research, we confirmed at the same study sites that the total dynamic activity of harvestmen showed significant positive relationship with proportion of $\mathrm{N}$ in the leaf litter, while the community equitability was negatively related to the $\mathrm{H}$ content of the soil (Litavský et al. 2018). As for the weevils, total dynamic activity of weevils showed a significant positive relationship with relative content of $\mathrm{H}$ in soil, while the species richness was negatively related to relative content of $\mathrm{H}$ and $\mathrm{N}$ in soil (Litavský et al. 2021b).

An important property of the soil is also its $\mathrm{pH}$. We found that $\mathrm{pH}$ was significantly positively correlated with species richness of rove beetle communities (Table 2 ). Soil pH probably had a positive effect on species richness of rove beetle communities, because the highest species richness appeared at the sites S5 (40 species) and S3 (39 species) (Table 1), on which the highest (S3 - 7.7) and the second highest pH of the soil (S5 - 7.6) (within the overall range 5.9-7.7) was recorded. The $\mathrm{pH}$ of soil and the leaf litter probably also had a positive effect on the Shannon's index of rove beetle communities, because its highest value was calculated for the site S2 (3.05) that was characterized by the highest pH of the leaf litter (6.4; within the overall range 5.3-6.4) and the second highest $\mathrm{pH}$ of the soil (7.6). Moreover, according to Irmler and Lipkow (2018), the acidity of substrate also plays a role in the distribution of staphylinid species.

In terms of vegetation properties, the number of plant species in shrub vegetation layer had the most significant effect on rove beetle communities. This property was significantly positively correlated with the total dynamic activity and species richness of rove beetle communities and negatively linked with evenness of these communities (Table 2). Rove beetle communities were probably also affected by the number of plant species in herb and tree layer, as well as stand canopy cover of shrub vegetation layer. 
This assumption suggests the finding that the highest values of the Shannon's index of rove beetle communities (3.05) (Table 1) was calculated for the site S2 with the highest number of plant species in tree vegetation layer (6 spp; within the overall range 0-6 spp). On the other hand, the second lowest number of plant species in herb vegetation layer (18 spp; within the overall range 16-32 spp) was found at the already mentioned sites S1 and S5 with the largest number of recorded individuals of staphylinids. In addition, the site $\mathrm{S} 1$ was characterised also by lowest stand canopy of shrub vegetation layer $(7 \%$; within the overall range 7-65\%). So, plant species richness of $E_{1}$ had the opposite effect on the rove beetle communities than plant species richness of $E_{2}$ and $E_{3}$. It remains questionable whether the high total dynamic activity of rove beetle communities at the $\mathrm{S} 1$ site was significantly affected by the low number of plant species in $E_{1}$ or the low canopy cover of $E_{2}$. The influence of vegetation structure on rove beetle communities was also pointed out by other authors. For example, Klimaszewski et al. (2018) claim that broadleaved and mixed forests provide for staphylinids richer and moister ground litter, which is a more suitable habitat for these beetles. According to Rose (2001) and Klimaszewski et al. (2018), canopy cover is the most important factor influencing the structure of rove beetle communities. During the same investigation, we found out that the total dynamic activity of weevils showed a significant positive relationship with number of plant species in shrub vegetation layer, while the species richness of weevils was significantly positively related to the number of plant species in herb and negatively to stand canopy of tree vegetation layers (Litavský et al. 2021b). We also found that, the harvestmen community equitability was positively related with species richness of plant communities in shrub layer (Litavský et al. 2018).

The obtained results also indicate the influence of other evaluated factors on rove beetle communities. For example, thickness of litter layer probably had a positive effect on the total dynamic activity as well as the species richness of the staphylinids. This is indicated by the fact that the already mentioned pair of sites S1 and S5, with the largest number of recorded individuals (Table 1) also had the thickest (S5 $4.2 \mathrm{~cm}$ ) and the second thickest litter layer $(\mathrm{S} 1-3.5 \mathrm{~cm}$ ) within all studied sites (within the overall range 1.0-4.2 cm). At the site S5, with the thickest litter layer, we recorded most species of rove beetles (Table 1). The influence of the litter layer on rove beetle communities was also pointed out by other authors. According to Klimaszewski et al. (2018), moist litter is a very important habitat for most rove beetles, because their small bodies are prone to desiccation. Removal of the litter layer and exposure of mineral soil likely reduce soil moisture and habitat suitability for staphylinids. Irmler and Lipkow (2018) pointed that litter type is the most important factor determining the distribution of rove beetles. According to these authors, several staphylinid species responded positively to high amounts of litter fall. The mentioned highest value of the Shannon's index of rove beetle communities, recorded at the site S2 may also point to the effect of stand age on these communities. In addition to the highest number of plant species in the tree vegetation layer, this site was also characterized by the oldest vegetation in tree layer (70 years; within the overall range 10-70 years). According to Pohl et al. (2008), many staphylinid species require continuous, mature, or old growth stands. Another important factor that probably shaped the structure of studied rove beetle communities was anthropogenic impact. Namely, the sites S3 and S5 with recorded highest species richness (Table 1), in addition to the relatively high pH values of the soil, were also 
characterised by the least anthropogenic impact (degree 1) within all studied sites (within the overall range degrees 1-4). The influence of anthropogenic impact on rove beetle communities was pointed out by several authors. For example, Pohl et al. (2008) pointed out that their species assemblages effectively reflect the extent of natural or human impact upon forest ecosystems. According to Klimaszewski et al. (2018), in many cases rove beetle species can be characterized as forest specialists with strong affinity for intact forest stands that have not been recently disturbed by forest management. Marcelino et al. (2016) studied the distribution and genetic variability of rove beetles in anthropogenically influenced insular landscapes. They found that rove beetle richness was associated with anthropogenic influence and habitat type, increasing from less to more anthropogenic impacted habitats.

Our research has revealed that wetland ecosystems in general, especially floodplain forests provide suitable conditions for staphylinid taxocoenoses with high species diversity. This diversity is conditioned by the fact that most species prefer moist habitats (Babenko et al. 2015; Irmler and Lipkow 2018; Klimaszewski et al. 2018) and also by diverse structure of microhabitats that floodplain forests provide to the rove beetles. The conservation and protection of these habitats is therefore important not only in terms of preserving rove beetle communities, but also in terms of maintaining high biodiversity and ecological stability in the landscape.

\section{Conclusions}

In summary, we examined how rove beetle communities vary across different habitats of river wetlands. During our investigation in the different stands of floodplain forests in Slovakia and Serbia, we found out that the total dynamic activity increased with species richness of shrub vegetation layer and the number of rove beetles was positively linked with the number of plant species in $\mathrm{E}_{2}$ and soil $\mathrm{pH}$. We also found that Ocypus (Ocypus) olens and Ocypus (Pseudocypus) mus preferred stands with higher soil pH and that these species could be used as suitable bioindicators to assess changes in landscape structure caused by human activity resulting in soil acidification. Therefore, more information about the importance of these relationships might be helpful in further elucidation of how rove beetle community metrics respond functionally to soil, vegetation, and microclimatic conditions, and how these conditions vary across various types of wetland habitats.

\section{Declarations}

\section{Acknowledgements}

This study was supported by project of Cultural and Educational Grant Agency No. 005PU-4/2019 and by the research grants 1/0658/19 and 1/0286/20 of the Slovak Grant Agency (VEGA).

\section{Author contributions}


J.L. and O.M. conceived and designed the study, conducted field work. O.M. processed biological samples. S.S. and J.L. interpreted data and wrote the first draft. M.S. performed statistical analyses and interpreted data. P.F. interpreted data. All authors contributed to writing, commented on the results, drafts and approved the final text.

\section{Funding}

This study was supported by project of Cultural and Educational Grant Agency No. 005PU-4/2019 and by the research grants 1/0658/19 and 1/0286/20 of the Slovak Grant Agency (VEGA).

\section{Conflicts of Interest/Competing Interests}

The authors declare no conflicts of interest/competing interest.

Soil sampling and beetle collection within the SNR "Ritovi donjeg Potisja" and SNR "Carska bara" were carried out on the basis of a permit of the Ministry of Agriculture and Environmental Protection of the Republic of Serbia based on the decision number 353-01-1529/2015-17. Soil and animal samples were taken in protected areas located in Slovakia based on a permission from the Ministry of the Environment of the Slovak Republic no: ou-ba-oszp1-2016/23797-sab.

\section{Ethics approval}

Not applicable.

\section{Consent to participate}

Not applicable.

\section{Consent for publication}

Not applicable.

\section{Availability of data and material}

All data produced from this study are provided in this manuscript.

\section{Code availability}


Not applicable.

\section{References}

1. Ábrahámová A, Kollár J, Žarnovičan H (2014) Vegetation of the Váh River Inundation in the Part Nové Mesto nad Váhom - Šal'a. Comenius University, Bratislava

2. Assing V, Schülke M (eds) (2012) Freude-Harde-Lohse-Klausnitzer - Die Käfer Mitteleuropas. Band 4. Staphylinidae I. Zweite neubearbeitete Auflage. Spektrum Akademischer Verlag, Heidelberg, Berlin

3. Babenko A, Touletaev S, Temnikova I (2015) Bio-diversity and population structure of rove beetles (Coleoptera, Staphylinidae) in the flood plain habitats of the $\mathrm{Ob}$ and Irtysh basin. Int $\mathrm{J}$ Environ Stud 72(3):516-520. https://doi.org/10.1080/00207233.2015.1027587

4. Betz O, Irmler U, Klimaszewski J (eds) (2018) Biology of Rove Beetles (Staphylinidae): Life history, Evolution, Ecology and distribution. Springer, Cham

5. Boháč J (1990) Numerical estimation of the impact of terrestrial ecosystems by using the staphylinid beetles communities. Agrochemistry and Soil Sciences 39:565-568

6. Boháč J (1999) Staphylinid beetles as bioindicators. Agric Ecosyst Environ 74:357-372. https://doi.org/10.1016/S0167-8809(99)00043-2

7. Boháč J, Bezděk A (2004) Staphylinid beetles recorded by pitfall and light trapping in Mrtvý luh peat bog. Silva Gabreta 10:141-149

8. Boháč J, Jahnová Z (2015) Land Use Changes and Landscape Degradation in Central and Eastern Europe in the Last Decades: Epigeic Invertebrates as Bioindicators of Landscape Changes. In: Armon $\mathrm{RH}$, Hanninen O (eds) Environmental Indicators, Springer, Dordrecht, pp 395-419. https://doi.org/10.1007/978-94-017-9499-2_24

9. Davis CA, Austin JE, Buhl DA (2006) Factors influencing soil invertebrate communities in riparian grasslands of the central Platte River floodplain. Wetlands 26:438-454.

https://doi.org/10.1672/0277-5212(2006)26[438:FISICI]2.0.C0;2

10. Dennis P, Aspinall RJ, Gordon IJ (2002) Spatial distribution of upland beetles in relation to landform, vegetation and grazing management. Basic Appl Ecol 3:183-193. https://doi.org/10.1078/14391791-00081

11. Derunkov AV (2004) Staphylinidae (Coleoptera) of the Pripiat River Floodplain, National Park 'Pripiatsky', Belarus. Acta Zoologica Lituanica 14(4):14-22

12. Derunkov AV (2007) Species diversity of Staphylinidae in the Neman river basin in Belarus. In: Schwenninger KW, Schawaller W (eds) 22nd International Meeting on Biology and Systematics of Staphylinidae. Staatliches Museum für Naturkunde, May 17-20, 2007. Stuttgart (Germany), pp 7-9

13. Derunkov AV (2009) The ecological and zoogeographical structure of the rove beetle assemblages (Coleoptera: Staphylinidae) in the floodplains of the large plain rivers (by the example of Belarus). Muzeul Olteniei Craiova. Oltenia. Studii şi comunicãri. Ştiinţele Naturii 25:105-110 
14. Dubovský M, Fedor P, Kucharczyk H, Masarovič R, Balkovič J (2010) Assemblages of bark-dwelling thrips (Thysanoptera) of uneven-aged oak forests in Slovakia. Sylwan 154:659-668

15. Dunger W (1958) Über die der Zersetzung Laubstreu durch die Boden-Makrofauna im Auenwald. Zoologische Jahrbücher 86:139-180

16. Fedor P (2004) First records of Dendrothrips degeeri Uzel, 1895 (Thysanoptera, Thripidae) in Slovakia. Biologia 59:211-212

17. Greenwood MT, Bickerton MA, Castella E, Large ARG, Petts GE (1991) The use of Coleoptera (Arthropoda: Insecta) for floodplain characterization on the River Trent, U.K. Regul Rivers: Res Manage 6(4):321-332. https://doi.org/10.1002/rrr.3450060410

18. Gutiérrez-Chacón C, Zúñiga MDC, Van Bodegom PM, Chará J, Giraldo LP (2009) Rove beetles (Coleoptera: Staphylinidae) in Neotropical riverine landscapes: characterising their distribution. Insect Conserv Diversity 2:106-115. https://doi.org/10.1111/j.1752-4598.2009.00050.x

19. Hadley D (2020) Habits and Traits of Rove Beetles, Family Staphylinidae. ThoughtCo, Retrieved from https://www.thoughtco.com/rove-beetles-family-staphylinidae-1968139. Accessed 15 September 2020

20. Harrell FE Jr (2016) Hmisc: Harrell Miscellaneous. R package version 3.17-14. https://cran.rproject.org/web/packages/Hmisc/index.html

21. Hughes FMR (2007) The importance of flooding regimes in the conservation of floodplain forests. International Symposium on River Restoration. October 23-24th, Madrid

22. Hughes FMR, del Tánago MG, Mountford JO (2012) Restoring Floodplain Forests in Europe. In: Stanturf J, Madsen P, Lamb D (eds) A Goal-Oriented Approach to Forest Landscape Restoration. World Forests. Springer, Dordrecht, pp 393-422. https://doi.org/10.1007/978-94-007-5338-9

23. Irmler U (1979) Abundance fluctuations and habitat ganges of soil Beatles in Central Amazonian inundation forests (Coleoptera: Carabidae and Staphylinidae). Studies on Neotropical Fauna and Environment 14:1-16

24. Irmler U, Lipkow E (2018) Effect of Environmental Conditions on Distribution Patterns of Rove Beetles. In: Betz O, Irmler U, Klimaszewski J (eds) Biology of Rove Beetles - Life History, Evolution, Ecology and Distribution. Springer, Cham, pp 117-144

25. Jost L (2006) Entropy and diversity. Oikos 113:363-375. https://doi.org/10.1111/j.2006.00301299.14714.x

26. King RS, Brazner JC (1999) Coastal wetland insect communities along a trophic gradient in Green Bay, Lake Michigan. Wetlands 19:426-437

27. Klimaszewski J, Brunke A, Work T, Venier L (2018) Rove beetles (Coleoptera, Staphylinidae) as bioindicators of change in boreal forests and their biological control services in agroecosystems: Canadian case studies. In: Betz O, Irmler U, Klimaszewski J (eds) Biology of Rove Beetles - Life History, Evolution, Ecology and Distribution. Springer, Cham, pp 161-181

28. Kolesnikova A, Lapteva E, Degteva S, Taskaeva A, Kudrin, A, Vinogradova Y, Khabibullina F (2016) Biodiversity of floodplain soils in the European north-east of Russia. In: Bucur D (ed) River basin 
management. IntechOpen, London, pp 271-294

29. Kontriš J (1981) Soil ecological and phytocoenological conditions of floodplain forests of the Liptov basin. Biologické práce 27:1-164

30. Litavský J, Majzlan O, Stašiov S, Svitok M, Fedor P (2021a) The associations between ground beetle (Coleoptera: Carabidae) communities and environmental condition in floodplain forests in the Pannonian Basin. Eur J Entomol 118:14-23. https://doi.org/10.14411/eje.2021.002

31. Litavský J, Majzlan O, Stašiov S, Svitok M, Žarnovičan H, Fedor P (2021b) Soil-dwelling communities of weevils (Coleoptera, Curculionoidea: Brentidae, Curculionidae) in Central European floodplain forests: a comparative interaction with environmental parameters. Biologia 76:179-192. https://doi.org/10.2478/s11756-020-00539-2

32. Litavský J, Stašiov S, Svitok M, Michalková E, Majzlan O, Žarnovičan H, Fedor P (2018) Epigean communities of harvestmen (Opiliones) in Pannonian Basin floodplain forests: an interaction with environmental parameters. Biologia 73:753-763. https://doi.org/10.2478/s11756-018-0084-8

33. Löbl I, Löbl D (eds) (2015) Catalogue of Palaearctic Coleoptera. Hydrophiloidea-Staphylinoidea. Vol. 2/1., Brill, Leiden, Boston

34. Lohse GA (1964) Band 4 Staphylinidae I (Micropeplinae bis Tachyporinae). In: Freude H, Harde KW, Lohse GA (eds) Die Käfer Mitteleuropas. Goecke \& Evers Verlag, Krefeld, pp 1-264

35. Lohse GA (1989) Ergänzungen und Berichtigungen zu Band 4. 23. Familie Staphylinidae (I) (Piestinae bis Tachyporinae). In: Lohse GA, Lucht WH (eds) Die Käfer Mitteleuropas. 1. Supplementband mit Katalogteil, Goecke \& Evers Verlag, Krefeld, pp 121-183

36. Newton AF (2019) StaphBase: Staphyliniformia world catalog database (version Nov 2018). In: Roskov Y, Ower G, Orrell T, Nicolson D, Bailly N, Kirk PM, Bourgoin T, DeWalt RE, Decock W, Nieukerken Evan, Zarucchi J, Penev L (eds) Species 2000 \& ITIS Catalogue of Life, 2019 Annual Checklist, Naturalis, Leiden. http://www.catalogueoflife.org/annual-checklist/2019/. Accessed 3 August 2020

37. Machar I (2008) Historical development of floodplain forests in the Upper Moravian Vale (Vrapač National Nature Reserve Czech Republic). Journal of Forest Science 54:426-437. https://doi.org/10.17221/46/2008-JFS

38. Majzlan O, Jászay T (1997) Taxocoenoses of rove beetles (Coleoptera, Staphylinidae) in the floodplain forest soils by Morava River (southwestern Slovakia). Folia faunistica Slovaca 2:61-69

39. Majzlan O, Litavský J (2017) Topical affinity of beetles (Coleoptera) to soil in floodplain forests along the Tisa and Begej rivers (Republic of Serbia). Entomofauna Carpathica 29:13-26

40. Marcelino JAP, Giordano R, Borges PAV, Garcia PV, Soto-Adames FN, Soares AO (2016) Distribution and genetic variability of Staphylinidae across a gradient of anthropogenically influenced insular landscapes. Bulletin of Insectology 69:117-126

41. Massolo A, Brandmayr P, Brandmayr TZ (2006) Predatory behaviour on ground beetles (Coleoptera: Carabidae) by Ocypus olens (Müller) (Coleoptera: Staphylinidae) under laboratory conditions. Entomological News, 117(5):545-551. https://doi.org/10.3157/0013872X(2006)117[545:PBOGBC]2.0.C0;2 
42. Michaels KF (2007) Using staphylinid and tenebrionid beetles as indicators of sustainable landscape management in Australia: a review. Australian Journal of Experimental Agriculture 47(4):435-449. https://doi.org/10.1071/EA06197

43. Michalko J, Berta J, Magic D (1986) Geobotanical map of Czechoslovakia, Slovak Socialist Republic. Veda, Bratislava

44. Ogai T, Kenta T (2016) The effects of vegetation types and microhabitats on carabid beetle community composition in cool temperate Japan. Ecol Res 31:177-188. https://doi.org/10.1007/s11284-015-1325-8

45. Oksanen J, Blanchet FG, Kindt R et al (2016) R package "vegan": Community ecology package. Version 2.3-4. https://cran.r-project.org/web/packages/vegan/index.html

46. Pohl G, Langor D, Klimaszewski J, Work T, Paquin P (2008) Rove beetles (Coleoptera: Staphylinidae) in northern forests. Can Entomol 140:415-436. https://doi.org/10.4039/n07-LS03

47. Porhajašová J, Petřvalský V, Šustek Z, Urminská J, Ondrišík P, Noskovič J (2008) Long-termed changes in ground beetle (Coleoptera: Carabidae) assemblages in a field treated by organic fertilizers, Biologia 63(6):1184-1195. https://doi.org/10.2478/s11756-008-0179-8

48. R Core Team (2016) R: a language and environment for statistical computing. R Foundation for Statistical Computing, Vienna. https://www.r-project.org/

49. Rose A (2001) Räumliche und zeitliche Verteilungsmuster der Kurzflügelkäfern (Coleoptera, Staphylinidae) auf Nordsee-Düneninseln unterschiedlicher Sukzessionsstadien. Archiv zoologischer Publikationen, 5:1-220

50. Rothenbücher J, Schaefer M (2006) Submersion tolerance in floodplain arthropod communities. Basic Appl Ecol 7:398-408. https://doi.org/10.1016/j.baae.2006.05.005

51. Schatz I (2007) Importance of riparian rove beetles (Coleoptera: Staphylinidae) as indicators for restoration processes. In: Füreder L (ed) International LIFE-Symposium: Riverine Landscapes. Natur in Tirol. (Naturkundliche Beiträge der Abteilung Umweltschutz), Innsbruck, pp 272-292

52. Skłodowski $J$ (2014) Consequence of the transformation of a primeval forest into a managed forest for carabid beetles (Coleoptera: Carabidae) a case study from Bialowieza (Poland). Eur J Entomol 111:639-648. https://doi.org/10.14411/eje.2014.088

53. Shepherd V (2013) Beetle diversity of chalk river floodplains. Dissertation, University College London

54. Spellerberg IF, Fedor PJ (2003) A tribute to Claude Shannon (1916- 2001) and a plea for more rigorous use of species richness, species diversity and the 'Shannon-Weiner index. Global Ecol Biogeogr 12:177-179

55. Sperduto DD, Nichols WF (2004) Natural communities of New Hampshire. New Hampshire Natural Heritage Bureau, Concord, New Hampshire

56. Stančić J (2013) Tvrdokrilci (Insecta: Coleoptera) Ramsko-Golubačke peščare (istočna Srbija). Acta entomologica serbica. Special Issue. Entomological Society of Serbia, Belgrade, pp 488

57. Stašiov S (2015) Ecology of Soil Organisms (Soil Animals). Technical University in Zvolen, Zvolen 
58. Štefánik M, Fedor P (2020) Environmental stress in Parnassius apollo reflected through wing geometric morphometrics in a historical collection with a possible connection to habitat degradation. Nat Conserv 38:79-99. https://doi.org/10.3897/natureconservation.38.48682

59. Šustek Z (1992) Expansion and ecology of Ocypus mus (Brullé, 1832), (Coleoptera, Staphylinidae) in Slovakia and Moravia. Biologia 47(2):129-133

60. Šustek Z (1994) Impact of water management on a Carabid community (Insecta Coleoptera) in a central European floodplain forest. Quaderni della Stazione di Ecologia del Civico Museo di Storia Naturale di Ferrara 6:293-313

61. Šustek Z (2003) Carabidae and Staphylinidae (Insecta, Coleoptera). Comparison of their response to changes in hydrological regimen in two floodplain forests. In: Hurtalová T, Orfánus T, Mikulec V, Bača P, Hamáček L, Matejka F (eds) Transport of Water, Chemicals and Energy in System Soil-Crop Canopy- Atmosphere. 11th International Poster Day, Bratislava, pp 387-396

62. Šustek Z (2006) Carabid and Staphylinid communities as indicators of changes in floodplain forests in the area affected by the Gabčíkovo project. In: Mucha I, Lisický MJ (eds) Slovak-Hungarian Environmental Monitoring of the Danube. Results of the Environmental Monitoring based on the "Agreement between the Government of the Slovak Republic and the Government of the Republic of Hungary concerning certain technical measures and discharges in the Danube and Mosoni branch of the Danube" 1995-2005. Slovak section. Danube Monitoring Scientific conference (25-26 May 2006), Mosonmagyaróvár, Hungary, pp 175-181

63. Thayer MK (2005) Staphylinidae Latreille, 1802. In: Beutel R, Leschen R (eds) Handbook of zoology: a natural history of the phyla of the animal kingdom. De Gruyter, New York, pp 296-344

64. Tuomisto H (2012) An updated consumer's guide to evenness and related indices. Oikos 121:12031218. https://doi.org/10.1111/j.1600-0706.2011.19897.x

65. Vašíček F (1985) Natural conditions of floodplain forests. In: Penka M, Vyskot M, Klimo E, Vašíček F (eds) Floodplain Forest ecosystem. 1. Before water management measures. Academia-Elsevier, Praha-Amsterdam, pp 13-29

66. Ward JV, Tockner K, Schiemer F (1999) Biodiversity of floodplain river ecosystems: ecotones and connectivity. Regul Rivers: Res Manage 15:125-139. https://doi.org/10.1002/(SICI)10991646(199901/06)15:1/3<125::AID-RRR523>3.0.CO;2-E

67. Wittich W (1942) Die Aktivierung von Rohhumus extrem ungünstiger Beschaffenheit. Zeitschrift für Forst- und Jagdwesen 74:241-271

68. Wittich W (1943) Untersuchungen über den Verlauf der Streuzersetzung auf einem Boden mit Mullzustand II. Forstarchiv 19:1-18

69. Zahradník P (2017) Check-list of Beetles (Coleoptera) of the Czech Republic and Slovakia. Lesnická práce, Kostelec nad Černými lesy

70. Zvaríková M, Kiselák J, Zvarík M, Masarovič R, Prokop P, Fedor P (2016) Ecological gradients and environmental impact in the forest dwelling Haplothrips subtilissimus (Thysanoptera: 
Phlaeothripidae) phenotypic variability. Ecol Indic 66:313-320.

https://doi.org/10.1016/j.ecolind.2016.01.038

\section{Tables}

\section{Table 1}

Total number of rove beetle specimens and the diversity measures of rove beetle communities recorded at the study sites $\mathrm{S} 1-\mathrm{S} 8$ 


\begin{tabular}{|c|c|c|c|c|c|c|c|c|c|c|}
\hline Taxon & Abbr. & & & & Site & & & & & $\Sigma$ \\
\hline & & S1 & S2 & S3 & S4 & S5 & S6 & S7 & S8 & \\
\hline $\begin{array}{l}\text { Acidota crenata } \\
\text { (Fabricius, 1792) }\end{array}$ & Accr & 1 & & & & & & & & 1 \\
\hline $\begin{array}{l}\text { Acrulia inflata } \\
\text { (Gyllenhal, 1813) }\end{array}$ & Acin & & 1 & & & 1 & & & & 2 \\
\hline $\begin{array}{l}\text { Aleochara } \\
\text { (Aleochara) curtula } \\
\text { (Goeze, 1777) }\end{array}$ & Alcu & 4 & & & & & & & & 4 \\
\hline $\begin{array}{l}\text { Aleochara } \\
\text { (Xenochara) } \\
\text { haemoptera Kraatz, } \\
1856\end{array}$ & Alha & 3 & 3 & & & & & & & 6 \\
\hline $\begin{array}{l}\text { Aleochara } \\
\text { (Aleochara) lata } \\
\text { Gravenhorst, } 1802\end{array}$ & Alla & & 5 & & 4 & & & & 2 & 11 \\
\hline $\begin{array}{l}\text { Aleochara } \\
\text { (Ceranota) ruficornis } \\
\text { Gravenhorst, } 1802\end{array}$ & Alru & & & & 1 & & & & & 1 \\
\hline $\begin{array}{l}\text { Aleochara } \\
\text { (Xenochara) sparsa } \\
\text { Heer, } 1839\end{array}$ & Alsp & & & & & & 15 & 17 & 3 & 35 \\
\hline $\begin{array}{l}\text { Aleochara } \\
\text { (Xenochara) tristis } \\
\text { Gravenhorst, } 1806\end{array}$ & Altr & & 4 & & & 12 & & & & 16 \\
\hline $\begin{array}{l}\text { Amischa analis } \\
\text { (Gravenhorst, 1802) }\end{array}$ & Aman & & & 2 & 4 & & & 1 & & 7 \\
\hline $\begin{array}{l}\text { Amphichroum } \\
\text { canaliculatum } \\
\text { (Erichson, 1840) }\end{array}$ & Amca & & 1 & & & & & & & 1 \\
\hline $\begin{array}{l}\text { Anthobium } \\
\text { atrocephalum } \\
\text { (Gyllenhal, 1827) }\end{array}$ & Anat & 4 & 5 & & & 6 & & & & 15 \\
\hline $\begin{array}{l}\text { Anthobium unicolor } \\
\text { (Marsham, 1802) }\end{array}$ & Anun & 1 & 3 & & & & & & & 4 \\
\hline $\begin{array}{l}\text { Anthophagus } \\
\text { (Phaganthus) } \\
\text { caraboides } \\
\text { (Linnaeus, 1758) }\end{array}$ & Anca & 1 & & & & 1 & & & & 2 \\
\hline $\begin{array}{l}\text { Arpedium quadrum } \\
\text { (Gravenhorst, 1806) }\end{array}$ & Arqu & & 1 & & & 1 & & & & 2 \\
\hline $\begin{array}{l}\text { Astenus (Astenus) } \\
\text { lyonessius (Joy, }\end{array}$ & Asly & & 2 & & & & & & & 2 \\
\hline
\end{tabular}


Batrisodes

Baad 1

(Batrisodes)

adnexus (Hampe, C.,

1863)

\section{Batrisodes}

Bave

(Batrisodes)

venustus

(Reichenbach, 1816)

Bisnius fimetarius

(Gravenhorst, 1802)

Bifi

10

2

5

17

Bledius (Bledius)

Bltr

1

tricornis (Herbst,

1784)

Bolitobius

castaneus

Boca

1

1

(Stephens, 1832)

Brachygluta

Brha 1

1

(Brachygluta)

haematica

(Reichenbach, 1816)

Bryaxis carinula

Brca 2

(Rey, 1888)

Chevrolatia egregia Cheg 1

Reitter, 1881

Cilea exilis

(Boheman, 1848)

Ciex

2

2

Claviger (Claviger)

Clte

testaceus Preyssler,

1790

Cypha longicornis

Cylo

2

3

5

(Paykull, 1800)

Dasycerus sulcatus

Dasu

1

Brongniart, 1800

Dinothenarus

Difo

1

(Parabemus) fossor

(Scopoli, 1771)

Domene (Domene) Dosc

scabricollis

(Erichson, 1840)

Drusilla (Drusilla)

Drca

2

3

14

5

2

4

11

canaliculata

(Fabricius, 1787) 
W. J. \& Kunze, 1822)

Eusphalerum $\quad$ Eulo 2
(Eusphalerum)
longipenne
(Erichson, 1839)

$\begin{aligned} & \text { Eusphalerum } \\ & \text { (Eusphalerum) } \\ & \text { luteum (Marsham, } \\ & \text { 1802) }\end{aligned}$

\section{Eusphalerum \\ (Eusphalerum) \\ signatum (Märkel, 1857)}

Eusi

\section{Falagria caesa}

Erichson, 1837

Geostiba (Geostiba) circellaris

(Gravenhorst, 1806)

Gyrohypnus

angustatus

Stephens, 1833

Phyllodrepa floralis Phfl 2

(Paykull, 1789)

Phyllodrepa nigra

(Gravenhorst, 1806)

Lathrobium

(Lathrobium)

Faca 5

Geci

1

4

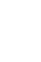

Gyan

1

2

Phni 4

Labr

2

4

brunnipes

(Fabricius, 1792)

Lathrobium

(Lathrobium)

Lael

elongatum

(Linnaeus, 1767)

Lathrobium

(Lathrobium)

longulum

Gravenhorst, 1802

Leptacinus

Lefo

formicetorum

Lalo

Märkel, 1841 


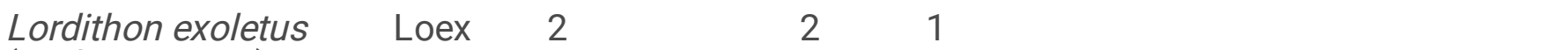

(Erichson, 1839)

Lordithon Iunulatus Lolu

4

(Linnaeus, 1767)

Meotica filiformis

Mefi

1

1

(Motschulsky, 1860)

Megarthrus

Mehe

1

hemipterus (Illiger,

1794)

Metopsia clypeata Mecl

4

(Müller, P. W. J.,

1821)

Micropeplus

porcatus (Paykull,

1789)

Mycetoporus

Mycl

4

4

clavicornis

(Stephens, 1832)

Mycetoporus

Mylo

1

longulus

Mannerheim, 1830

Neuraphes

(Neuraphes)

Neca

2

2

carinatus (Mulsant

\& Rey, 1861)

Neuraphes

(Neuraphes)

elongatulus (Müller,

P. W. J. \& Kunze,

1822)

Nudobius lentus

Nule

1

4

5

(Gravenhorst, 1806)

Ocalea (Ocalea)

Ocba

22

4

badia Erichson,

1837

Ocypus

(Angulephallus)

$\begin{array}{lll}\text { Ocbr } & 10 \quad 9\end{array}$

2

6

8

35

brunnipes Fabricius,

1781

Ocypus

(Pseudocypus)

fulvipennis

Erichson, 1840

Ocypus

Ocmu

Ocfu

(Pseudocypus) mus 
Brullé, 1832

$\begin{array}{llllllll}\text { Ocypus (Matidus) } & \text { Ocni } & 8 & 8 & 8 & 18 & 3\end{array}$

nitens (Schrank,

1781)

$\begin{array}{lllllll}\text { Ocypus (Ocypus) } & \text { Ocol } & 26 & 4 & 67 & 75 & 34\end{array}$

olens Müller, O. F.,

Ocol $26 \quad 4$

67

34

1764

Ocypus (Ocypus) Ocop

1999

37

ophthalmicus

(Scopoli, 1763)

Oligota granaria

Olgr

1

1

Erichson, 1837

Olophrum consimile

Olco

1

1

(Gyllenhal, 1810)

Olophrum Olpu 1

4

5

puncticolle

Eppelsheim, 1881

Omalium caesum

Gravenhorst, 1806

Omalium

Omox

4

4

oxyacanthae

Gravenhorst, 1806

Omalium rivulare

Omri

10

10

(Paykull, 1789)

Ontholestes haroldi Onha

5

5

(Eppelsheim, 1884)

Othius subuliformis Otsu

2

2

Stephens, 1833

Ontholestes

Onte

3

12

15

tessellatus

(Geoffroy, 1785)

Oxyporus

$\begin{array}{llll}\text { Oxma } & 2 & 1 & 2\end{array}$

3

8

maxillosus

Fabricius, 1792

Oxytelus

Oxsc

2

sculpturatus

(Gravenhorst, 1806)

Paederus

Paba 4

2

6

(Paederus)

balcanicus Koch,

1938

Paederus

$\begin{array}{lll}\text { Pali } & 1 & 2\end{array}$

(Poederomorphus) 
littoralis

Gravenhorst, 1802

Philonthus

Phca

(Philonthus)

carbonarius

(Gravenhorst, 1802)

Philonthus

Phco

$1 \quad 1$

(Philonthus)

cognatus Stephens,

1832

Philonthus

(Philonthus)

Phco

21

concinnus

(Gravenhorst, 1802)

Philonthus

(Philonthus) jurgans

Phju

1

Tottenham, 1937

Philonthus

(Onychophilonthus)

Phma

3

marginatus (Müller,

O. F., 1764)

Philonthus

Phpa

4

4

(Philonthus)

parvicornis

(Gravenhorst, 1802)

Philonthus

(Philonthus)

Phsp 2

$4 \quad 1$

5

13

25

spinipes Sharp,

1874

Phloeonomus

(Phloeonomus)

Phpu 1

pusillus

(Gravenhorst, 1806)

Platydracus

PIfu

2

12

5

19

(Platydracus)

fulvipes (Scopoli,

1763)

Platydracus

Plch 4

1

5

(Platydracus)

chalcocephalus

(Fabricius, 1801)

Platydracus

Plst

1

(Platydracus)

stercorarius (Olivier,

1795)

Platystethus

Plar

arenarius (Geoffroy, 
1785)

\begin{tabular}{|c|c|c|c|}
\hline $\begin{array}{l}\text { Proteinus } \\
\text { brachypterus } \\
\text { (Fabricius, 1792) }\end{array}$ & Prbr & 1 & 1 \\
\hline
\end{tabular}

Proteinus crenulatus Prcr

Pandellé, 1867

$\begin{array}{lllll}\text { Proteinus laevigatus } & \text { Prla } & 2 & 1 & 3\end{array}$

Hochhuth, 1872

$\begin{array}{llllr}\begin{array}{l}\text { Pselaphus heisei } \\ \text { Herbst, } 1791\end{array} & \text { Pshe } & 3 & & 5 \\ \begin{array}{l}\text { Quedius (Quedius) } \\ \text { balticus Korge, 1960 }\end{array} & \text { Quba } & 5 & 5 \\ \begin{array}{l}\text { Quedius (Raphirus) } \\ \text { boops (Gravenhorst, } \\ \text { 1802) }\end{array} & \text { Qubo } & 3 & 3\end{array}$

Quedius

(Microsaurus) brevis

Qubr

1

Erichson, 1840

Quedius

(Microsaurus)

Qucr

$\begin{array}{lll}1 & 1 & 3\end{array}$

cruentus (Olivier, A.

G., 1795)

Quedius

Quin

12

2

(Microsaurus)

infuscatus Erichson,

1840

Quedius (Quedius)

Qule

2

levicolls

Quedius (Raphirus)

Quma

3

maurorufus

(Gravenhorst, 1806)

Quedius

(Microsaurus)

Quxa

2

xanthopus Erichson,

1839

Rugilus (Rugilus)

Ruer

1

erichsoni (Fauvel,

1867)

Rybaxis longicornis Rylo

(Leach, 1817)

Scaphium

Scim

immaculatum

(Olivier, A.G., 1790) 
Scaphidium

Scqa 2

quadrimaculatum

Olivier, A. G., 1790

Scydmaenus

Sche 1

1

(Cholerus) hellwigii

(Herbst, 1791)

Siagonium

Siqu

1

quadricorne Kirby et

Spence, 1815

Staphylinus

Stca $\quad 45$

21

9

5

80

caesareus

Cederhjelm, 1798

Stenichnus

(Stenichnus) bicolor

Stbi

2

(Denny, 1825)

Stenichnus

Stco

2

(Stenichnus) collaris

(Müller, P. W. J. \&

Kunze, 1822)

Stenichnus

Stgo

1

(Stenichnus) godarti

(Latreille, 1806)

Stenus

Stbi

1

1

(Metatesnus)

binotatus Ljugh,

1804

Stenus (Stenus)

Stcl

4

clavicornis (Scopoli,

1763)

Stenus

(Metatesnus)

Stfl

2

2

flavipes Stephens,

1833

Stenus (Stenus)

juno (Paykull, 1789)

Stenus

Stoc

Stju

16

7

(Hemistenus)

ochropus

Kiesenwetter, 1858

Stenus

(Hemistenus)

Stpa

2

2

4

pallipes

Gravenhorst, 1802

Tachinus (Tachinus) Tabi

bipustulatus

(Fabricius, 1792) 
Tachinus (Tachinus) Tafi

fimetarius

Gravenhorst, 1802

Tachinus (Tachinus) Tahu

humeralis

Gravenhorst, 1802

Tachinus (Tachinus) Tapa

pallipes

(Gravenhorst, 1806)

Tachyporus

(Tachyporus)

Taab

2

1

2

abdominalis

(Fabricius, 1782)

Tachyporus

Tahy

2

hypnorum

(Fabricius, 1775)

Tasgius

(Rayacheila)

Tagl

2

5

7

globulifer (Geoffroy,

1785)

Tasgius

(Rayacheila)

$\begin{array}{llll}\text { Tame } & 1 & 9 & 3\end{array}$

melanarius (Heer,

1839)

\section{Tetartopeus}

quadratus (Paykull,

Tequ

1789)

Trimium brevicorne Trbr

(Reichenbach, 1816)

Tyrus mucronatus Tymu

(Panzer, 1803)

Xantholinus

Xali 1

24

3

9

(Xantholinus)

linearis (Olivier, A.

G., 1795)

Xantholinus

(Xantholinus)

Xalo

longiventris Heer,

1839

Zyras (Zyras)

collaris (Olivier,

Zyco

1

1795)

Zyras (Zyras)

Zyha $\quad 12$

1832) 


\begin{tabular}{|llllllllll|}
$\Sigma$ ex. & 265 & 126 & 178 & 219 & 252 & 107 & 63 & 73 & 1283 \\
\hline$\Sigma$ spp. & 35 & 34 & 39 & 35 & 40 & 17 & 17 & 15 & 130 \\
\hline Shannon diversity & 2.34 & 3.05 & 2.61 & 2.44 & 2.54 & 2.41 & 2.41 & 2.48 & \\
\hline Evenness & 0.30 & 0.62 & 0.35 & 0.33 & 0.32 & 0.66 & 0.66 & 0.80 & \\
\hline
\end{tabular}

\section{Table 2}

Matrix of Spearman correlation coefficients between community characteristics and environmental variables: soil (s), leaf litter (I), stand canopy of individual vegetation layers $\left(E_{1}, E_{2}, E_{3}[\%]\right)$, species richness of individual layers $\left(E_{1}, E_{2}, E_{3}\right.$ species) and the acidity measured in the supernatant suspension of a 1:2.5 soil: $\mathrm{H}_{2} \mathrm{O}\left(\mathrm{pH}_{\mathrm{H} 2 \mathrm{O}}\right)$, conductivity in $\mathrm{H}_{2} \mathrm{O}$ extract $\left(\kappa\left[\mu \mathrm{S} . \mathrm{cm}^{-1}\right]\right)$, phosphorus $(\mathrm{P})$, nitrogen $(\mathrm{N})$, carbon $(C)$, hydrogen $(H)$, \%weighted $(\% W)$. Statistically significant correlations $(a=5 \%)$ are highlighted in bold 


\begin{tabular}{|c|c|c|c|c|}
\hline Environmental parameters & Dynamic activity & Species richness & Shannon diversity & Evenness \\
\hline Anthropic impact & -0.06 & 0.01 & -0.01 & -0.28 \\
\hline $\mathrm{E}_{1}[\%]$ & 0.04 & 0.22 & 0.06 & -0.16 \\
\hline $\mathrm{E}_{2}[\%]$ & -0.42 & 0.18 & 0.31 & 0.13 \\
\hline $\mathrm{E}_{3}[\%]$ & 0.25 & -0.19 & -0.47 & 0.00 \\
\hline $\mathrm{E}_{1}$ species & -0.16 & 0.22 & 0.59 & 0.04 \\
\hline$E_{2}$ species & 0.78 & 0.77 & -0.04 & -0.90 \\
\hline$E_{3}$ species & -0.22 & -0.15 & 0.29 & 0.17 \\
\hline Area $\left[\mathrm{m}^{2}\right]$ & 0.14 & -0.34 & -0.21 & 0.24 \\
\hline Edge $[\mathrm{m}]$ & 0.31 & -0.25 & -0.40 & 0.07 \\
\hline Circuit [m] & -0.12 & -0.61 & -0.50 & 0.48 \\
\hline Age [year] & -0.06 & -0.27 & -0.04 & -0.01 \\
\hline Litter depth [cm] & 0.14 & -0.12 & -0.24 & 0.00 \\
\hline $\mathrm{pH}_{\mathrm{H} 2 \mathrm{O}} / \mathrm{s}$ & 0.51 & 0.78 & 0.56 & -0.63 \\
\hline $\mathrm{pH}_{\mathrm{H} 2 \mathrm{O}} / \mathrm{l}$ & 0.20 & 0.43 & 0.49 & -0.39 \\
\hline $\mathrm{k}\left[\mathrm{mS} \cdot \mathrm{cm}^{-1}\right] / \mathrm{s}$ & -0.07 & -0.22 & 0.31 & 0.10 \\
\hline $\mathrm{k}\left[\mathrm{mS} . \mathrm{cm}^{-1}\right] / \mathrm{l}$ & -0.38 & -0.51 & 0.00 & 0.40 \\
\hline $\mathrm{P}\left[\mathrm{mg} \cdot \mathrm{kg}^{-1}\right] / \mathrm{s}$ & 0.19 & -0.20 & 0.07 & 0.00 \\
\hline $\mathrm{P}\left[\mathrm{mg} \cdot \mathrm{kg}^{-1}\right] / \mathrm{I}$ & -0.17 & -0.60 & -0.29 & 0.36 \\
\hline$N[\%] / s$ & 0.01 & -0.47 & -0.40 & 0.23 \\
\hline$N[\%] / I$ & -0.64 & -0.22 & 0.02 & 0.43 \\
\hline $\mathrm{C}[\%] / \mathrm{s}$ & 0.26 & 0.20 & 0.21 & -0.38 \\
\hline C [\%]/I & 0.10 & -0.06 & -0.67 & -0.17 \\
\hline $\mathrm{H}[\%] / \mathrm{s}$ & -0.57 & -0.87 & -0.38 & 0.69 \\
\hline $\mathrm{H}[\%] / /$ & -0.24 & -0.31 & -0.52 & 0.24 \\
\hline
\end{tabular}

Figures 


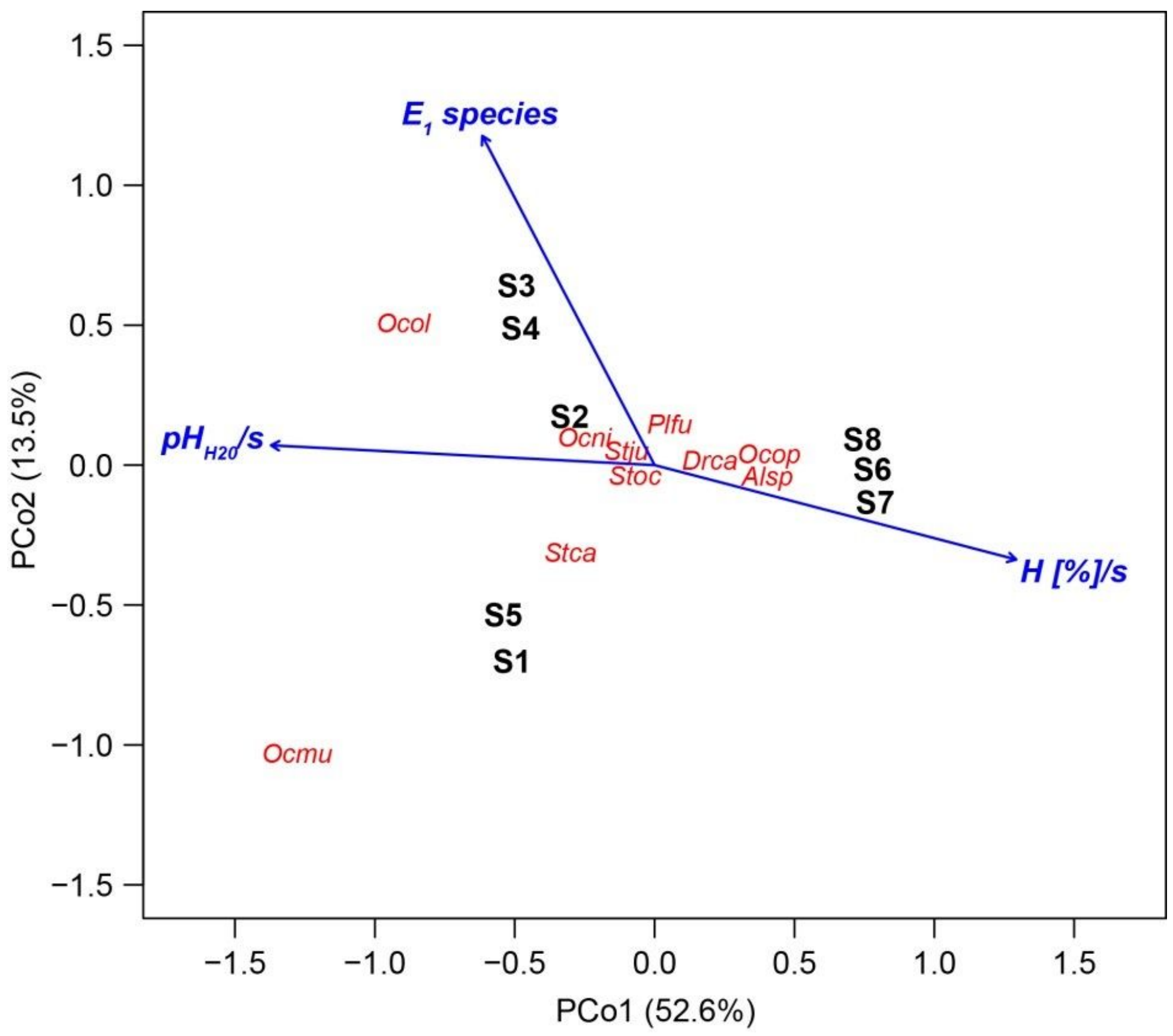

Figure 1

Ordination plot of PCoA showing similarity of rove beetle communities based on Bray-Curtis distances of epigeic activities. The vectors of significant environmental variables are fitted onto the ordination in direction of their maximal correlation. Scores of the species (in red) with the best fit to significant environmental variables were added as weighted averages of site scores. Proportion of variation accounted for the ordination axes is displayed in parentheses. For abbreviations of species names see table 1 